\title{
Novel milk casein-derived peptides decrease cholesterol micellar solubility and cholesterol intestinal absorption in Caco-2 cells
}

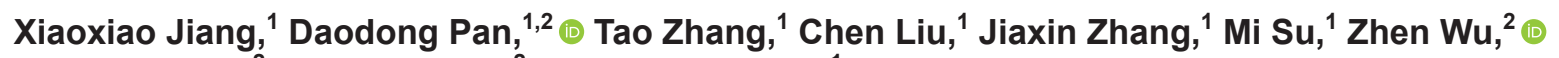 \\ Xiaoqun Zeng, ${ }^{2}$ Yangying Sun, ${ }^{2}$ (D) and Yuxing Guo ${ }^{1 *}$ (D) \\ ${ }^{1}$ Department of Food Science and Technology, School of Food Science and Pharmaceutical Engineering, Nanjing Normal University, \\ 210023 China \\ ${ }^{2}$ Food and Pharmaceutical Sciences College, Ningbo University, 315800 China
}

\begin{abstract}
This study sought to assess the cholesterol-lowering activity of peptides obtained from milk casein hydrolyzed with neutrase. The bioactive peptides were separated using a Sephadex G-10 chromatographic column (Amersham Pharmacia Biotech, Uppsala, Sweden) after ultrafiltration using a 1-kDa molecular mass cutoff membrane. Via ultra-performance liquid chromatography-electrospray ionization-tandem mass spectrometry, we determined that peptides Thr-Asp-Val-Glu-Asn [TDVEN; $\beta$-casein $\mathrm{f}(143-147)], \quad$ Leu-Gln-Pro-Glu [LQPE; $\beta$-casein f(103-106)], Val-Ala-Pro-Phe-Pro-Glu [VAPFPE; $\alpha_{\mathrm{S}_{1}}$-casein $\mathrm{f}(40-45)$ ], and Val-Leu-Pro-ValPro-Gln [VLPVPQ $\beta$-casein f(185-190)] reduced micellar cholesterol solubility. After Caco-2 cells were treated with LQPE, VLPVPQ, and VAPFPE, the NiemannPick C1-Like 1 (NPC1L1) protein levels decreased by $($ means \pm SEM) $19.33 \pm 2.47 \%, 52.1 \pm 3.77 \%$, and $23.09 \pm 8.52 \%$, respectively, compared with the control group. Treatment with each peptide induced significant upregulation of ATP binding cassette subfamily G member 8 antibody ( $A B C G 8)$ mRNA expression by $398.1 \pm 23.27 \%, 86.4 \pm 27.07 \%$, and $92.8 \pm 8.49 \%$. We found that VLPVPQ and LQPE significantly upregulated ATP-binding cassette transporter A1 (ABCA1) transcription by $203.9 \pm 8.44 \%$ and $220.8 \pm 36.42 \%$ respectively, whereas VLPVPQ significantly decreased mRNA expression of acetyl-CoA-acetyltransferase 2 (ACAT2) and microsomal triacylglycerols $(M T P)$. The cholesterol-lowering action of milk-derived peptides may be induced by suppression of micellar cholesterol solubility and affects the expression of cholesterol absorption-related proteins and enzymes in intestinal epithelial cells. This research discovers new milk-derived peptides with decreasing cholesterol micellar solubility
\end{abstract}

Received September 12, 2019.

Accepted January 1, 2020.

*Corresponding author: guoyuxing1981@163.com and provides a theoretical basis of in vitro cholesterollowering effects of peptides.

Key words: bioactive peptides, milk casein, cholesterollowering solubility of micellar, NPC1L1, Caco-2 cells

\section{INTRODUCTION}

Hyperlipidemia, arteriosclerosis, and other cardiovascular diseases caused by excessive cholesterol levels have major and widespread negative effects on human health (Musso et al., 2010; Gaudet et al., 2017). The homeostatic balance of cholesterol favorably influences blood fat levels (Xiao et al., 2016). Diet and lifestyle changes and pharmacological treatment have been proposed to deal with hypercholesterolemia in humans (Zhao et al., 2012). Functional foods may be able to play a preventive role for moderate hypercholesterolemia (Chen et al., 2011; Braithwaite et al., 2014). Many studies have reported hypolipidemic actions of plant peptides, such as soybean-derived peptide LPYPR (Zhang et al., 2013), WGAPSL (Zhang et al., 2013), and VAWWMY (Nagaoka et al., 2010). Milk-derived bioactive peptides can be regarded as potential functional food ingredients (Nagaoka et al., 2001; Korhonen, 2009; Beermann and Hartung, 2013; Martínez-Augustin et al., 2014; Suwal et al., 2019). Lactostatin (IIAEK) and $\beta$-lactotensin (HIRL) derived from milk lactoglobulin were identified as hypocholesterolemic peptides (Nagaoka et al., 2001; Yamauchi et al., 2003).

Mechanisms of hypolipidemic peptides on cholesterol-lowering activity include bile acid binding (Nagaoka et al., 2001; El-Tantawy and Temraz, 2019), inhibition of micellar solubility of cholesterol in vitro and cholesterol absorption in vivo (Nagaoka, 2019), inhibition of 3-hydroxy-3-methylglutaryl CoA reductase (HMGCoAR) activity (Boachie et al., 2018), and targeting of the expression of proteins involved in cholesterol metabolism (Duranti et al., 2004; Moriyama et al., 2004). Cholesterol homeostasis is maintained by a complex mechanism of sterol absorption, anabolism, catabolism, 
and excretion (Nagaoka, 2018). Cholesterol, either from diet or from bile, is transported into enterocytes via intestinal Niemann-Pick C1-like 1 (NPC1L1). Intestinal acyl coenzyme A:cholesterol acyltransferase 2 (ACAT2) esterifies cholesterol to form cholesteryl ester, which is packed with microsomal triacylglycerols (MTP) into chylomicrons and transferred into blood through the lymphatic system. Adenosine triphosphate (ATP)-binding cassette transporters combined with transporter $\mathrm{G}$ superfamily member 8 antibodies (ABCG8) then return unabsorbed cholesterol to the lumen of the intestine for excretion (Chen et al., 2011). Caco-2 cell monolayers have routinely been used as an in vitro model to mimic substance absorption by the human intestinal epithelium (Picariello et al., 2013): NPC1L1 (Alrefai et al., 2007), ABCG8 (Ito et al., 2012), SREBP-2 (Field et al., 2001), ACAT2 (Song et al., 2006), and MTP (Mathur et al., 1997) are all expressed in the Caco-2 cell model. Nagaoka et al. (1997) reported that the suppression of cholesterol intestinal epithelia absorption by Caco-2 cell studies is part of the mechanism for the hypocholesterolemic action. Yang et al. (2018) explored the effects of 6 fatty acids on cholesterol uptake in human Caco-2 cells (enterocytes), and on the mRNA expression levels of the previously listed genes.

The purpose of this study was to purify the potential cholesterol-lowering peptides derived from hydrolyzed casein protein and characterize their amino acid sequences. The effects of Leu-Gln-Pro-Glu (LQPE), ValAla-Pro-Phe-Pro-Glu (VAPFPE), and Val-Leu-ProVal-Pro-Gln (VLPVPQ) on cholesterol absorption were analyzed using Caco-2 cell experiments, and expression of key genes that influence cholesterol absorption was studied. This study may promote the use of hydrolyzed peptides from casein protein as bioactive ingredients in functional foods.

\section{MATERIALS AND METHODS}

\section{Chemicals and Reagents}

Cells from the Caco-2 human colorectal adenocarcinoma cell line were purchased from the Institute of Biochemistry and Cell Biology (CAS; Shanghai, China). Fetal bovine serum and coverslips were purchased from Solarbio Science and Technology (Beijing, China). Cell culture medium, Dulbecco's modified Eagle's medium (DMEM), and trypsin were purchased from Hyclone Laboratories (Logan, UT). Hanks' balanced salt solution (HBSS) and PBS were purchased from Gibco Invitrogen (Burlington, Canada). Water-soluble cholesterol was purchased from Sigma-Aldrich (Shanghai,
China), and LQPE, VAPFPE, and VLPVPQ identified by ultra-high-performance liquid chromatography (UPLC)-MS were synthesized by Shanghai Bootech BioScience and Technology (Shanghai, China) with over $95 \%$ purity based on reverse-phase (RP) HPLC$\mathrm{MS} / \mathrm{MS}$.

\section{Production and Ultrafiltration of Casein Hydrolysates}

An aqueous casein solution (5\% wt/vol, protein basis) was adjusted to $\mathrm{pH}$ 7.0. The casein protein solution was hydrolyzed with neutrase $(50 \mathrm{U} / \mathrm{mg})$ at $48^{\circ} \mathrm{C}$ for 3.5 h. Hydrolysis $\mathrm{pH}$ was maintained at 7.0. After 3.5 $\mathrm{h}$ the reaction was stopped by heating the solution to $90^{\circ} \mathrm{C}$ for $20 \mathrm{~min}$ to inactivate the enzymes. After centrifugation at $7,000 \times g$ for $20 \mathrm{~min}$, supernatant was collected. Fractionation was carried out using hollow fiber ultrafiltration membrane (Shanghai Mosu Science Equipment Co. Ltd., Shanghai, China) at a flow rate of $7.5 \mathrm{~mL} / \mathrm{min}$ and a membrane pressure of $0.25 \mathrm{MPa}$. The fraction below $1 \mathrm{kDa}$ was lyophilized and stored at $-20^{\circ} \mathrm{C}$ for subsequent purification.

\section{Purification and Identification of Casein Peptides}

The hydrolysate was applied to a Sephadex G-10 column $(1.0 \times 40 \mathrm{~cm}$, Amersham Pharmacia Biotech, Uppsala, Sweden) equilibrated with distilled water. Peptides were eluted with distilled water at a flow rate of $3.5 \mathrm{~mL} / \mathrm{min}$. Elution curves were obtained by measuring absorbance at $220 \mathrm{~nm}$. The fractions were collected at 2-min intervals. The experiments were conducted at room temperature using MA99-2A Protein Chromatography Equipment (Shanghai Huxi Analysis Instrument Factory, Shanghai, China). The fractions were pooled and concentrated by freeze-drying. The protein concentration and inhibition activity of micellar solubility of cholesterol were then analyzed. The fraction with the highest activity was applied to UPLC-MS.

\section{Inhibition Activity of Micellar Solubility of Cholesterol}

Micellar cholesterol solubility was measured after adding $3 \mathrm{mg} / \mathrm{mL}$ of each peptide fraction to a suspension of intestinal micelles prepared in vitro. Cholesterol micelles were prepared according to the method of Zhang et al. (2012) with some modifications. Sodium phosphate buffer at pH 7.4 containing $6.6 \mathrm{mmol} / \mathrm{L}$ taurocholate and $132 \mathrm{mmol} / \mathrm{L} \mathrm{NaCl}$ salts was mixed with $2 \mathrm{mmol} / \mathrm{L}$ cholesterol and $1 \mathrm{mmol} / \mathrm{L}$ linoleic acid. To form the micelles, the suspension was sonicated twice for 1 min using a Misonix 3000 sonicator (Misonix, 
New York, NY) at 95\% energy output (114 W). The supernatant fractions were filtered through a $0.22-\mu \mathrm{m}$ Millex-GP filter (Millipore, Bedford, MA). The supernatant fractions $(25 \mu \mathrm{L})$ were collected, and cholesterol concentrations were determined using an Amplex Red Cholesterol Assay Kit (Thermo Fisher Scientific, Waltham, MA) by measuring the absorbance at 510 $\mathrm{nm}$. Cholesterol concentrations were determined from standard curves using cholesterol calibration standards. Cholesterol concentrations and inhibition ability were calculated using the following equations:

$$
\begin{gathered}
\text { Concentration of cholesterol }(\mathrm{mmol} / \mathrm{L})=\left(\mathrm{OD}_{\mathrm{s}} / \mathrm{OD}_{\mathrm{c}}\right) \\
\times[\text { concentration of calibrator }(\mathrm{mmol} / \mathrm{L})], \quad[1]
\end{gathered}
$$

where $\mathrm{OD}_{\mathrm{c}}$ is the calibrator's absorbance measured by optical density and $\mathrm{OD}_{\mathrm{s}}$ is the sample's absorbance; and

$$
\text { Inhibition ability }(\%)=\left[\left(\mathrm{C}_{\mathrm{o}}-\mathrm{C}_{\mathrm{s}}\right) / \mathrm{C}_{\mathrm{o}}\right] \times 100 \%,[2]
$$

where $\mathrm{C}_{\mathrm{o}}$ is the cholesterol concentration of the original micelles and $\mathrm{C}_{\mathrm{s}}$ is the cholesterol concentration after the peptide fraction was added (Zhang et al., 2012; Marques et al., 2015a).

\section{Identification of Amino Acid Sequences of Casein Peptides}

The molecular mass of peptides purified by gel filtration with the highest inhibition micellar cholesterol solubility activity was determined using a Waters MALDI SYNAPT Q-TOF mass spectrometer (Milford, MA). The sequences were determined by secondary ion mass spectrometry performed with the same system. Samples were dissolved to a concentration of approximately $10 \mathrm{ppm}$ in methanol and analyzed by infusion of the sample $(8 \mu \mathrm{L})$ through the electrospray interface. The UPLC analysis was performed at $45^{\circ} \mathrm{C}$ using an Acquity UPLC BEH130 $\mathrm{C}_{18}$ column $(2.1 \times 150 \mathrm{~mm}$, $1.7 \mu \mathrm{m}$; Waters).

Elution was performed with $100 \%$ acetonitrile (solvent $\mathrm{A}$ ) and $0.1 \%$ methanoic acid in $\mathrm{H}_{2} \mathrm{O}$ (solvent $\mathrm{B}$ ). Peptides were eluted with a linear gradient of solvent A going from 2 to $40 \%$ in $10 \mathrm{~min}, 40$ to $100 \%$ in the next $5 \mathrm{~min}$, remaining at $100 \%$ for $2 \mathrm{~min}$, and then going to $2 \%$ in the next $5 \mathrm{~min}$, and solvent B going from 98 to $60 \%$ in $10 \mathrm{~min}$ and 60 to $0 \%$ in the next 5 min, remaining there for $2 \mathrm{~min}$, and then to $98 \%$ in the next 5 $\mathrm{min}$. The flow rate was $0.3 \mathrm{~mL} / \mathrm{min}$. The variable wavelength absorbance detector was set at $204 \mathrm{~nm}$, and an automatic injector was used. Mass data were obtained using an electrospray ionization in positive-ion mode and was calibrated using the lock-mass function with leucine encephalin. Conditions of MS were as follows: ion source and polarity were electrospray ionization; capillary voltages $3,500 \mathrm{~V}$; sampling cone voltages 30 $\mathrm{V}$; source temperature $100^{\circ} \mathrm{C}$; desolvation temperature $300^{\circ} \mathrm{C}$; desolvation gas flow $500 \mathrm{~L} / \mathrm{h}$; cone gas flow 50 $\mathrm{L} / \mathrm{h}$; and detecting voltage 1,600 to $1,700 \mathrm{~V}$. Nitrogen was used as the sheath and auxiliary gas at pressures of 35 and 3 arbitrary units, respectively. Argon was used as the target gas (3 mTorr) for the collision. Collision energy was set at $6 / 35 \mathrm{~V}$. Mass spectra were acquired over 100 to $1,500 \mathrm{~m} / z$.

Data were collected and analyzed with Waters MassLynx v. 4.1 and BiopharmaLynx 1.3.3 software. Peptide identification involved the search for the masses in the NCBI database of bovine casein proteins and matching the MS/MS spectrum with the sequences selected by mass. We used GPMAW 8.0 software (Lighthouse Data, Odense, Denmark) and Mascot Server (Matrix Science Inc., Boston, MA) to identify peptide sequences.

\section{Cell Culture Conditions}

The Caco-2 cells were cultured in high-glucose DMEM with stable L-glutamine supplemented with $10 \%$ fetal bovine serum, $100 \mathrm{U} / \mathrm{mL}$ penicillin, and 100 $\mu \mathrm{g} / \mathrm{mL}$ streptomycin (complete growth medium) in a fully humidified atmosphere with $5 \% \mathrm{CO}_{2}$ at $37^{\circ} \mathrm{C}$. Cell culture medium was replaced every other day, and cells were passaged 1:2 after the confluent rate reached 70 to $80 \%$.

\section{MTT Assay}

Cell viability was measured by 3-(4,5-dimethylthiazol-2-yl)-2,5-diphenyltetrazolium bromide (MTT) assay. The Caco-2 cells were seeded in a 96-well plate with DMEM at 7,500 cells/well and incubated for 24 h. After the old medium was discarded, the cells were incubated in the complete growth medium containing different concentrations $(0.05,0.1,0.2$, and $0.4 \mathrm{mg} / \mathrm{mL})$ of 4 synthetic peptides (TDVEN,VLPVPQ, LQPE, and VAPFPE) or DMEM for $24 \mathrm{~h}$. Then the treatment solvent was aspirated, and $100 \mu \mathrm{L} /$ well of filtered MTT solution was added. After $2 \mathrm{~h}$ of incubation at $37^{\circ} \mathrm{C}$ in a $5 \% \mathrm{CO}_{2}$ atmosphere, the $0.5 \mathrm{mg} / \mathrm{mL}$ solution was aspirated, and $100 \mu \mathrm{L} /$ well of lysis buffer $(8 \mathrm{mmol} / \mathrm{L}$ $\mathrm{HCl}+0.5 \% \mathrm{NP}-40$ in dimethyl sulfoxide) was added. After $5 \mathrm{~min}$ of slow shaking, the absorbance at 570 nm was read on a Tecan PRO M200 microplate reader (Mannedorf, Switzerland). Cell viability (\%) was expressed as OD ratio of the treatment to the control. 


\section{Effects of LQPE, VAPFPE, and VLPVPQ on Cholesterol Absorption in Caco-2 Cells in Vitro}

Caco- 2 cells $\left(2 \times 10^{5}\right.$ cells $/ \mathrm{cm}^{2}$ at passage 36$)$ were seeded in Transwell permeable membrane $(1.12-\mathrm{cm}$ diameter, $0.4-\mu \mathrm{m}$ pore size; Corning Life Sciences, Corning, NY). The DMEM culture medium $(0.5 \mathrm{~mL})$ containing the cells was added to the apical-side (AP) well and $1.5 \mathrm{~mL}$ of DMEM culture was added to the basolateral-side (BL) well. After inoculation, the fluid was changed every other day. The DMEM was changed every second day for 1 week and then changed every day until a monolayer formed. The integrity of the cell layer was tested by measuring the transepithelial electrical resistance (TEER; Guo et al., 2018) using a Millicell Voltohmmeter (Millipore, Bedford, MA). Cell permeability measurements were conducted in triplicate. Only Caco- 2 cell monolayers with TEER values greater than $500 \Omega \cdot \mathrm{cm}^{2}$ were used for the transport studies (Srinivasan et al., 2015). Alkaline phosphatase, which is the signature enzyme of the brush-border cells of the intestinal epithelium when cells begin to differentiate, was measured using a commercial AKP assay kit (Nanjing Jiancheng Bioengineering Institute, Nanjing, China) in accordance with the manufacturer's instructions.

The prepared Caco-2 cell monolayer were washed with PBS twice and nurtured with PBS in $5 \% \mathrm{CO}_{2}$ at $37^{\circ} \mathrm{C}$ for $30 \mathrm{~min}$. The PBS was replaced with $0.5 \mathrm{~mL}$ of LQPE, VAPFPE and VLPVPQ $(1 \mathrm{mmol} / \mathrm{L})$ on the AP side and $1.5 \mathrm{~mL}$ fresh PBS on the BL side. The PBS was removed from the AP side and replaced with 0.5 $\mathrm{mL}$ of PBS control. All the plates were incubated at $37^{\circ} \mathrm{C}$ in $5 \% \mathrm{CO}_{2}$. After incubation for another $2 \mathrm{~h}$, the peptide transportation in the BL side of each well were determined by UPLC-MS.

The permeability coefficients $\left(\mathbf{P}_{\text {app }}, \mathrm{cm} / \mathrm{s}\right)$ were used to evaluate permeability of peptides through Caco-2 cells, according to Eq. [3] (Sienkiewicz-Szłapka et al., 2009):

$$
\mathrm{P}_{\text {app }}=\left(\mathrm{d} Q \times \mathrm{d} t^{-1}\right) \times\left(A \times C_{0}\right)^{-1},
$$

where $\mathrm{d} Q \times \mathrm{d} t^{-1}$ is the function of the amount and time of the peptides present on the BL side $(\mu \mathrm{mol} / \mathrm{s})$, and the amounts of peptides were calculated using a peptide standard curve; and $A\left(\mathrm{~cm}^{2}\right)$ and $C_{0}(\mu \mathrm{mol} / \mathrm{L})$ are the surface area of the monolayer and the initial peptide concentration on the AP side, respectively.

Water-soluble cholesterol was dissolved in the complete medium at $4 \mathrm{mg} / \mathrm{mL}$. We dissolved LQPE, VLPVPQ, and VAPFPE in sterile PBS with the concentration adjusted to $0.05,0.1,0.2$, and $0.4 \mathrm{mg} / \mathrm{mL}$, and then sterilized them using a $0.22-\mu \mathrm{m}$ microwell filter. The culture medium in the Transwell plate was removed and washed with $1 \mathrm{~mL}$ of PBS solution 3 times. We added $1 \mathrm{~mL}$ of cholesterol solution to the blank control group, and $900 \mu \mathrm{L}$ of cholesterol solution and $100 \mu \mathrm{L}$ of LQPE, VAPFPE, or VLPVPQ solution to the experimental group at different concentrations, respectively, on the AP side. We added DMEM culture medium $(1.5 \mathrm{~mL})$ to the $\mathrm{BL}$ side in all groups. After incubating at $37^{\circ} \mathrm{C}$ in $5 \% \mathrm{CO}_{2}$ for $24 \mathrm{~h}$, the well solution was discarded and washed with $1 \mathrm{~mL}$ of PBS solution 3 times. The Caco- 2 cells were digested by trypsin and centrifuged at $1,000 \times g$ for $10 \mathrm{~min}$ at $4^{\circ} \mathrm{C}$ to collect cell pellets. Caco-2 cell pellets were washed twice with $0.1 \mathrm{~mol} / \mathrm{L}$ phosphate buffer ( $\mathrm{pH} 7.2$ ) and centrifuged at $1,000 \times g$ for $10 \mathrm{~min}$ at $4^{\circ} \mathrm{C}$. The cells were resuspended in $0.3 \mathrm{~mL}$ of $0.1 \mathrm{~mol} / \mathrm{L}$ phosphate buffer $(\mathrm{pH} 7.2)$ and sonicated in an ice-water bath $(300 \mathrm{~W}, 5 \mathrm{~s}$ each at 30 -s intervals for 5 repetitions). According to a Total Cholesterol kit (Nanjing Jiancheng Bioengineering Institute, Nanjing, China), absorbance was measured at $510 \mathrm{~nm}$, and the cholesterol content in the cells was calculated according to Equation [1] (Zhang et al., 2012).

\section{Casein Peptides Regulating Cholesterol Absorption in Caco-2 cell model}

The Caco-2 cell monolayers cultured in Transwell plate were rinsed with HBSS twice and incubated with HBSS for $30 \mathrm{~min}$ at $37^{\circ} \mathrm{C}$ in $5 \% \mathrm{CO}_{2}$ when the cell monolayer models were formed. Micellar cholesterol was prepared as described in the section "Inhibition Micellar Cholesterol Solubility Activity." The HBSS was removed and replaced with micellar cholesterol, micellar cholesterol $+0.1 \mathrm{mg} / \mathrm{mL}$ LQPE, micellar cholesterol $+0.1 \mathrm{mg} / \mathrm{mL}$ VLPVPQ, or micellar cholesterol $+0.05 \mathrm{mg} / \mathrm{mL}$ VAPFPE on the AP side (amounts of peptides were according to MTT results) and $1.5 \mathrm{~mL}$ of fresh complete medium on the $\mathrm{BL}$ side. All of the plates were incubated at $37^{\circ} \mathrm{C}$ in $5 \% \mathrm{CO}_{2}$. After incubation for another $24 \mathrm{~h}$, the cells were lysed to extract total RNA, nuclear protein, and cytoplasm protein to assay cholesterol absorption gene and protein expression.

\section{RNA Extraction and qPCR Assay}

Total RNA was extracted from Caco-2 cells using the RNeasy Mini kit following the manufacturer's suggested protocol (Qiagen, Germantown, MD). RNA concentration was measured by spectrophotometry using a NanoDrop (NanoDrop Technologies, Wilmington, DE). We evaluated RNA integrity using the Bioanalyzer 2100 (Agilent Technologies, Santa Clara, CA), and only 
Table 1. Primer sequences used for real-time quantitative (RT-q) PCR analysis

\begin{tabular}{ll}
$\begin{array}{l}\text { Gene } \\
\text { symbol }\end{array}$ & Primer sequences $\left(5^{\prime}-3^{\prime} ; \mathrm{F}=\right.$ forward, $\mathrm{R}=$ reverse $)$ \\
\hline ACTB & F: 5'-CACGATGGAGGGGCCGGACTCATC-3' \\
& R: 5'-TAAAGACCTCTATGCCAACACAGT-3' \\
NPC1L1 & F: 5'-TCCTCTTTCTGAACCGCTACTT-3' \\
& R: 5'-TCAGGGAACTCTGTGGCATACT-3' \\
ABCG8 & F: 5'-TACCTCATCGTCATTGGCCT-3' \\
& R: 5'-GAGTGCAGTTGAAGGGTCTG-3' \\
ACAT2 & F: 5'-GCGGACCATCATAGGTTCCTT-3' \\
& R: 5'-ACTGGCTTGTCTAACAGGATTCT-3' \\
MTP & F: 5'-GGGCTCTTGACCCGTTTGAA-3' \\
& R: 5'-TCGTCTCTCCTAAGGTCTTTGG-3' \\
ABCA1 & F: 5'-TGTGGCTTTTGGGTTTGG-3' \\
& R: 5'-GGAGACCGAAGTGGTGAGATT-3' \\
SREBP-1 & F: 5'-ACCGTTTCTTCGTGGATGG-3' \\
SREBP-2 & R: 5'-AGTGCTCGCTCTAAGAGATGTTC-3' \\
& F: 5'-TTGGATGATGCTAAGGTCAAAGA-3' \\
& R: 5'-CCCACTGCAGCAGGGAAGT-3' \\
\hline
\end{tabular}

samples with an RNA integrity number $\geq 8$ were used for the mRNA experiments. The cDNA was produced from $1 \mu \mathrm{g}$ of total RNA by Superscript II Reverse Transcriptase (Invitrogen, Carlsbad, CA), and mRNA expression was measured by TaqMan quantitative PCR (qPCR) assay. We performed PCR amplification of cDNA as shown in Table 1.

The qPCR assays were carried out in 96-well plates using a 7500 Fast Real-Time (RT)-PCR system (Applied Biosystems, Waltham, MA). Amplification parameters were used for PCR as follows: $50^{\circ} \mathrm{C}$ for 2 min, $95^{\circ} \mathrm{C}$ for $10 \mathrm{~min}$, and 40 cycles of amplification at $95^{\circ} \mathrm{C}$ for $15 \mathrm{~s}$ and $60^{\circ} \mathrm{C}$ for $1 \mathrm{~min}$. Eight reference genes were tested: $A C T B, N P C 1 L 1, A B C G 8, A C A T 2, M T P$, $A B C A 1, S R E B P 1$, and SREBP2. Normalized mRNA expressions were calculated using the comparative cycle threshold (CT) method based on the $2^{-\Delta \Delta \mathrm{CT}}$ formula (Livak and Schmittgen, 2001). Data are presented as the average of a minimum of 5 replicates.

\section{Western Blotting of NPC1L1}

For preparation of whole-cell extracts, cells were harvested using a cell scraper and lysed with ice-cold radioimmunoprecipitation assay (RIPA) buffer containing protease-inhibitor cocktail (Sigma-Aldrich, St. Louis, MO) and phosphatase inhibitors (Roche Diagnostics, Mannheim, Germany). The total cell lysates were then centrifuged at $10,000 \times g$ for $20 \mathrm{~min}$ at $4^{\circ} \mathrm{C}$ to remove the insoluble materials. The protein concentrations were determined using a BCA protein assay kit (Pierce Biotechnology Inc., Rockford, IL). Cytoplasmic and nuclear extracts were prepared with nuclear and cytoplasmic extraction reagents from Beyotime (Nan- tong, Jiangsu, China) according to the manufacturer's instructions. Forty micrograms of each protein extract were separated using 12\% PAGE and electro-transferred to polyvinylidene difluoride membranes at $20 \mathrm{~V}$ for $60 \mathrm{~min}$. The membranes were blocked with $5 \%$ skim milk in tris-buffered saline containing $0.1 \%$ Tween-20 (TBST). After washing with TBST, the membranes were incubated with target-protein-specific antibodies for $14 \mathrm{~h}$ at $4^{\circ} \mathrm{C}$, followed by incubation with horseradish peroxidase-conjugated secondary antibodies for 1 h. Peroxidase activity was visualized using an enhanced chemiluminescence kit (Bio-Rad, Hercules, CA). Imaging was performed via G: BOX chemiXR5 (Syngene, Frederick, MD). Grayscale analysis of the results was performed using Gel-Pro32 software (Media Cybernetics, Rockville, MD). For equal loading and normalization purposes, $\beta$-actin was used as an internal control (Lammi et al., 2015).

\section{Calculations and Statistics}

Statistical analyses were carried out via one-way ANOVA (SPSS Statistics 20; IBM Corp., Armonk, NY) followed by Dunnett's test. Results were expressed as mean \pm SD. Differences were considered significant at $P<0.05$ and extremely significant at $P<0.01$.

\section{RESULTS}

\section{Purification and Identification of Peptides from the Casein Protein Hydrolysate}

After $3.5 \mathrm{~h}$ of hydrolysis with neutrase, casein fractions were fractionated through ultrafiltration membranes with $1 \mathrm{kDa}$ cutoff values. The fractions with molecular weight $<1 \mathrm{kDa}$ were subjected to size-exclusion chromatography on a Sephadex G-10 column. Two subfractions (A and B) were obtained (Figure 1A). Fraction A displayed higher micellar cholesterol solubility activity than fraction $\mathrm{B}$, both at concentrations of $100 \mu \mathrm{g} / \mathrm{mL}$. The cholesterol micelle solubility inhibition rate of fraction A was $24.20 \pm 0.24 \%$, and that of fraction B was $4.30 \pm 0.16 \%$ (Table 2). Fraction A was selected for further UPLC-MS analysis to analyze the amino acid sequences of the peptides. The chromatogram results for HBSS and fraction A are shown in Figure 1B and 1C. As analyzed with a protein and peptide editor program, 4 possible amino acid sequences for the casein-derived peptides were analyzed from fraction A (Table 3): TDVEN [ $\beta$-casein $\mathrm{f}(143-147)$, Figure 2A], LQPE [ $\beta$-casein $\mathrm{f}(103-106)$, Figure 2B], VLPVPQ [ $\beta$-casein $\mathrm{f}(185-190)$, Figure $2 \mathrm{C}]$, and VAPFPE $\left[\alpha_{\mathrm{s} 1}\right.$-casein $\mathrm{f}(40-45)$, Figure $2 \mathrm{D}]$. 
A

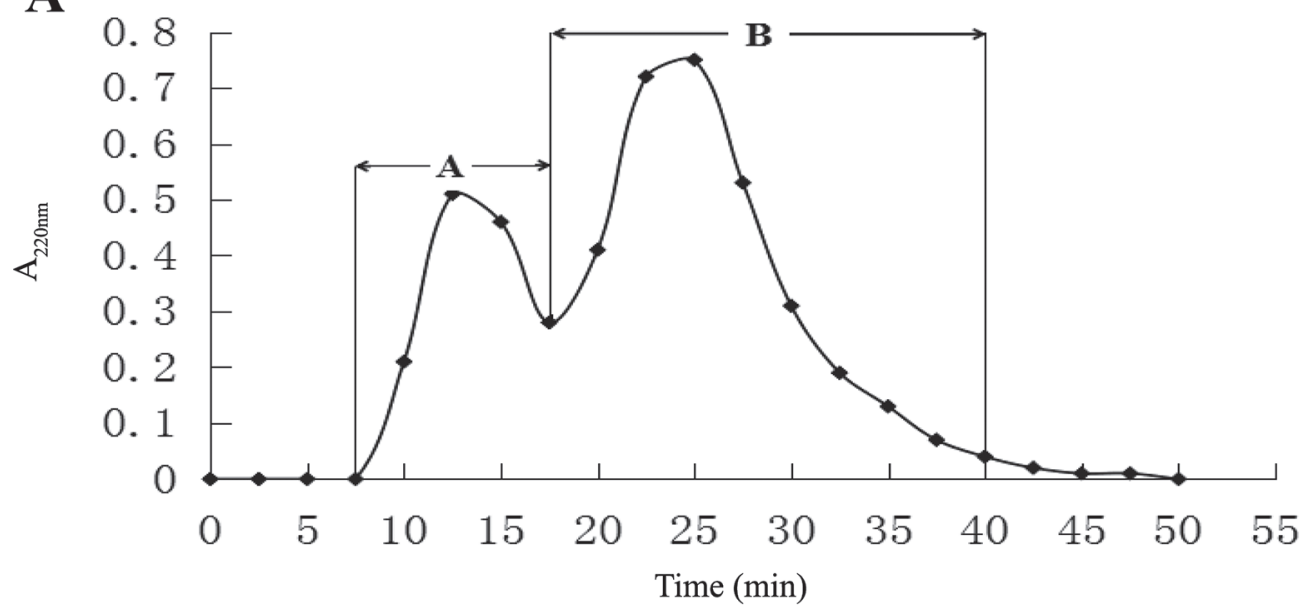

B
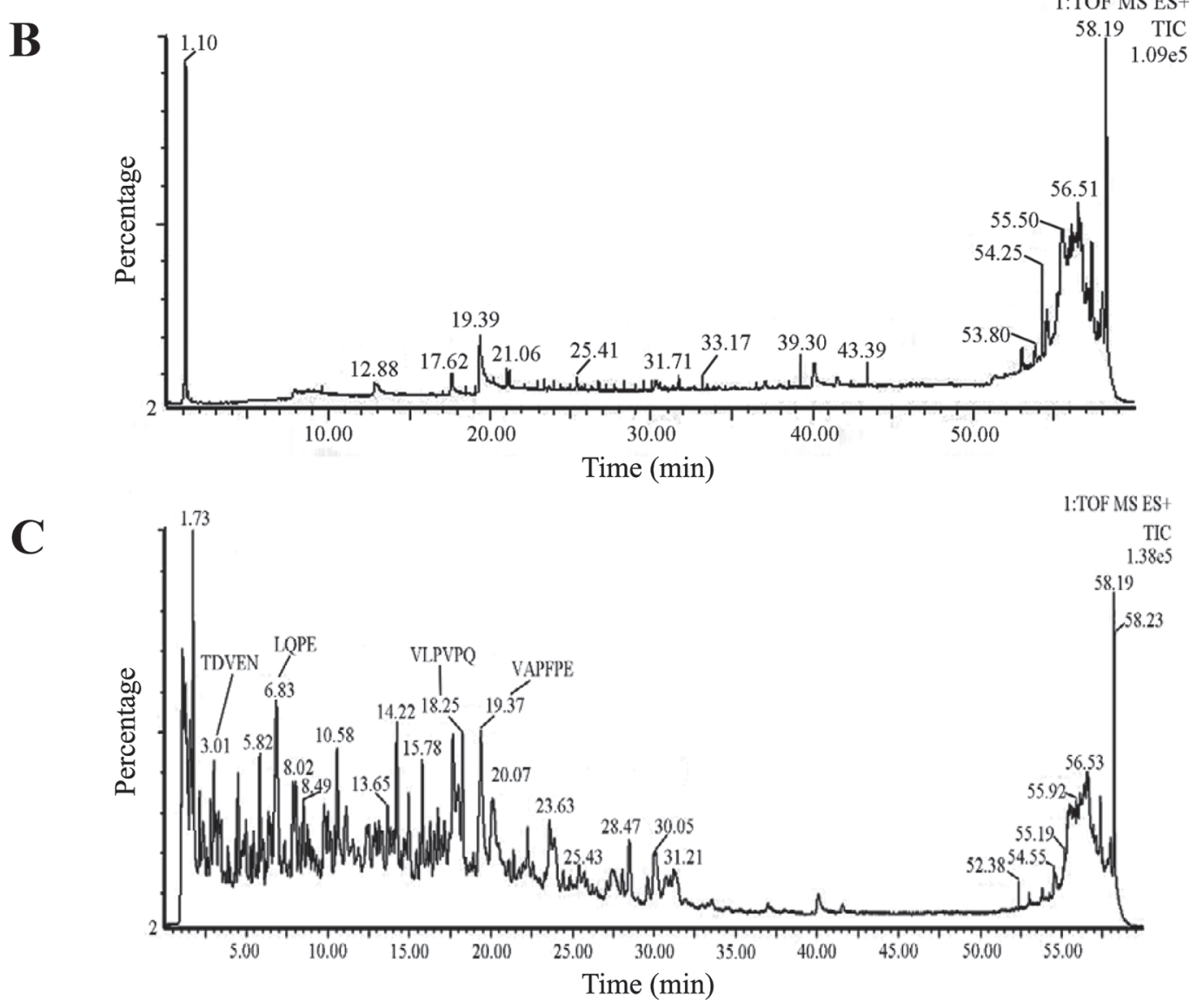

Figure 1. (A) Elution profile of fractions A and B separated by gel filtration on Sephadex G-10 (Amersham Pharmacia Biotech, Uppsala, Sweden). A220 $\mathrm{nm}=$ absorbance at $220 \mathrm{~nm}$. (B) Chromatogram of Hanks' balanced salt solution by ultra-high-performance liquid chromatography (UPLC)-MS. (C) Chromatogram of sample A by UPLC-MS. TDVEN, LQPE, VLPVPQ, VAPFPE = milk-derived peptides.

\section{Effects of TDVEN, LQPE, VAPFPE, and VLPVPQ Peptides on Micellar Cholesterol Solubility in Vitro}

The TDVEN, LQPE, VAPFPE, and VLPVPQ peptides were synthesized at $95 \%$ purity. Cholesterol micelles with 4 peptides at concentrations of $0.2 \mathrm{mg} /$ $\mathrm{mL}$ were configured. After TDVEN, LQPE, VAPFPE, and VLPVPQ were incubated with cholesterol micelles for $24 \mathrm{~h}$, ultracentrifugation was used to determine the cholesterol content in the supernatant. As shown 
Table 2. Inhibition of cholesterol solubility of casein-derived peptides in vitro, data presented as mean $\pm \mathrm{SD}$ with 3 samples from each group; $P$-values $<0.05$ were considered significant (Tukey test on oneway ANOVA, SPSS Statistics 20; IBM Corp., Armonk, NY)

\begin{tabular}{lc}
\hline Sample & $\begin{array}{c}\text { Cholesterol solubility } \\
\text { inhibition rate }(\%)\end{array}$ \\
\hline Fraction A of Sephadex G-10 & $24.20 \pm 0.24^{\mathrm{d}}$ \\
Fraction B of Sephadex G-10 & $4.30 \pm 0.16^{\mathrm{e}}$ \\
TDVEN & $48.37 \pm 4.42^{\mathrm{b}}$ \\
LQPE & $46.30 \pm 0.84^{\mathrm{b}}$ \\
VLPVPQ & $52.80 \pm 1.35^{\mathrm{a}}$ \\
VAPFPE & $32.11 \pm 1.74^{\mathrm{c}}$ \\
\hline
\end{tabular}

${ }^{1}$ Amersham Pharmacia Biotech, Uppsala, Sweden.

in Table 2, the peptides had a certain inhibitory effect on the dissolution of cholesterol. The inhibition rate of cholesterol dissolution in cholesterol micelles by VLPVPQ reached $52.80 \%$. The inhibitory effects of LQPE and TDVEN were obvious at $46.30 \%$ and $48.37 \%$, respectively. The inhibition rate of VAPFPE was lower than those of the others, at $32.11 \%$.

\section{MTT Experiments of LQPE, VAPFPE, and VLPVPQ on Caco-2 Cell Viability}

We performed MTT experiments to exclude any potential toxic effects of peptides on the Caco-2 cell line. Because these are slow-growing cells with an average doubling time of about $24 \mathrm{~h}$, they were incubated for 1 $\mathrm{d}$ with LQPE, VAPFPE, or VLPVPQ before the MTT assay was performed. Because TDVEN could not be completely dissolved in DMEM, it was not included in cell culture experiments. No significant cell mortality was observed, with the peptide concentrations ranging from 0.1 to $0.4 \mathrm{mg} / \mathrm{mL}$. When the concentrations of the 3 proteins was $0.2 \mathrm{mg} / \mathrm{mL}$, the survival rate of the cells was more than $98 \%$. When the protein concentration was $0.1 \mathrm{mg} / \mathrm{mL}$, the cell survival rate was $99 \%$, which did not affect cell growth (Figure 3A). For this reason, in the following experiments, designed to investigate the functional effects of the peptides, the optimum concentrations of LQPE and VLPVPQ were $0.1 \mathrm{mg} /$ $\mathrm{mL}$, and the optimum concentration of VAPFPE was $0.05 \mathrm{mg} / \mathrm{mL}$.

\section{Peptides Affect Cholesterol Absorption in Caco-2 Cells}

The integrity of the Caco-2 monolayer was checked consistently via TEER measurements (Figure 3B). The $\mathrm{P}_{\text {app }}$ of LQPE was $2.75 \times 10^{-6} \mathrm{~cm} / \mathrm{s}$, VAPFPE was $1.73 \times 10^{-6} \mathrm{~cm} / \mathrm{s}$, and VLPVPQ was $6.68 \times 10^{-6} \mathrm{~cm} / \mathrm{s}$ (Figure 3C). Figure 3D shows the effect of milk-derived peptides on the absorption of water-soluble cholesterol in Caco-2 cells. After $24 \mathrm{~h}$ of Caco-2 cell uptake experiments, the cholesterol concentration of the blank control group in the Caco-2 cells was $0.1136 \mathrm{mg} / \mathrm{mL}$. At $0.05,0.1,0.2$, and $0.4 \mathrm{mg} / \mathrm{mL}, \mathrm{LQPE}$ and VLPVPQ significantly inhibited cholesterol uptake in the Caco-2 cells. At $0.4 \mathrm{mg} / \mathrm{mL}$ LQPE had the most obvious effect on decreasing cholesterol absorption, with an inhibition rate of $87.66 \%$.

The VAPFPE peptide also inhibited the absorption of cholesterol by Caco-2 cells, and the absorbance was significantly lower than that of the blank control group $(P<0.01)$. The inhibitory effect of the 3 peptides was significantly different. At $0.05 \mathrm{mg} / \mathrm{mL} \mathrm{LQPE}$ and VLPVPQ, the inhibition rate on Caco-2 cell monolayer cholesterol absorption was more than $50 \%$, significantly higher than that of VAPFPE, which was $13.65 \%(P<$ $0.01)$. At $0.1 \mathrm{mg} / \mathrm{mL}$, VLPVPQ inhibited cholesterol absorption in Caco-2 cells from monolayers significantly more than it did at $0.05 \mathrm{mg} / \mathrm{mL}(P<0.01)$. The inhibitory effect of 0.2 and $0.4 \mathrm{mg} / \mathrm{mL}$ LQPE was not significantly different than that of $0.4 \mathrm{mg} / \mathrm{mL}$ VLPVPQ $(P$ $>0.05)$. The results indicated dose-dependent effects of peptides concentration on the inhibitory effect on the cholesterol absorption of Caco-2 cells.

\section{Effects of LQPE, VAPFPE, and VLPVPQ on NPC1L1 Protein Expression}

To confirm the ability of LQPE, VAPFPE, and VLPVPQ to inhibit the catalytic activity of NPC1L1, an in vitro assay was performed using the purified casein peptides. Caco-2 cells were treated with $0.1 \mathrm{mg} / \mathrm{mL}$ LQPE, $0.1 \mathrm{mg} / \mathrm{mL}$ VLPVPQ, or $0.05 \mathrm{mg} / \mathrm{mL}$ VAPFPE with cholesterol micelles on the AP side. Each sample was investigated with immunoblotting experiments. As

Table 3. Sequence of 4 casein-derived peptides ${ }^{1}$

\begin{tabular}{lccllr}
\hline Fraction & Retention time & Mass $\left(\left[\mathrm{M}+\mathrm{H}^{+}\right]\right)$ & Sequence & Origin & GRAVY \\
\hline 1 & 3.01 & 577.24 & TDVEN & $\beta$-casein $\mathrm{f}(143-147)$ & -1.4 \\
2 & 6.83 & 486.24 & LQPE & $\beta$-casein $\mathrm{f}(103-106)$ & 3.01 \\
3 & 18.25 & 652.42 & VLPVPQ & $\beta$-casein f(185-190) & -1.2 \\
4 & 19.37 & 659.35 & VAPFPE & $\alpha_{\text {S1 }}$-casein $\mathrm{f}(40-45)$ & 0.92 \\
\hline
\end{tabular}

${ }^{1}$ Grand average of hydropathicity (GRAVY) and isoelectric point (pI) were computed using https://web.expasy.org/protparam/. Negative GRAVY values indicate hydrophilicity; positive values indicate hydrophobicity. 
$\mathbf{A}$
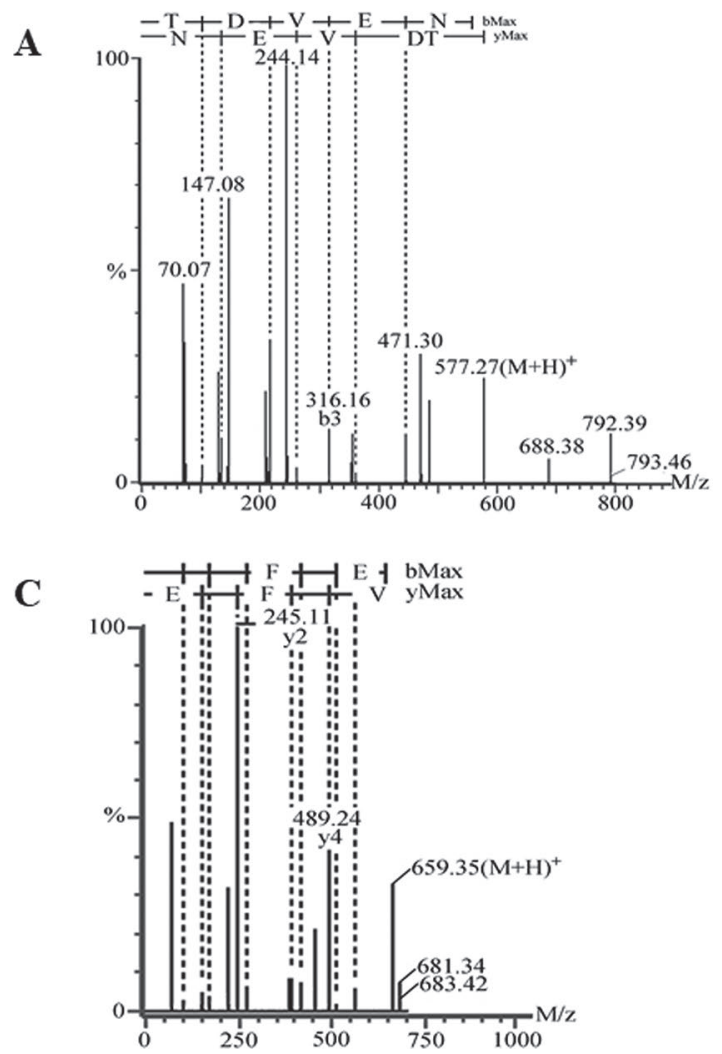

B

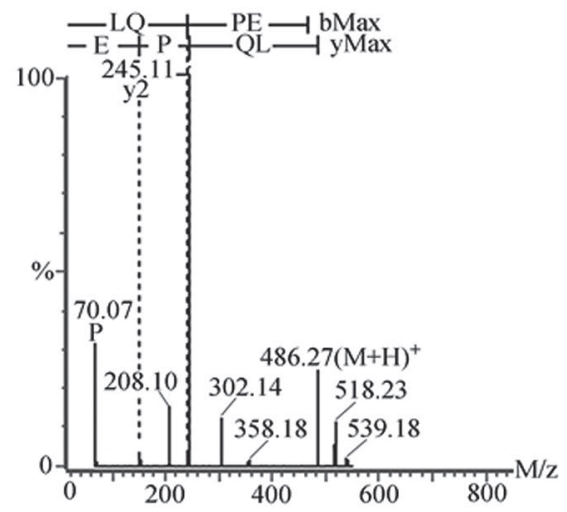

D

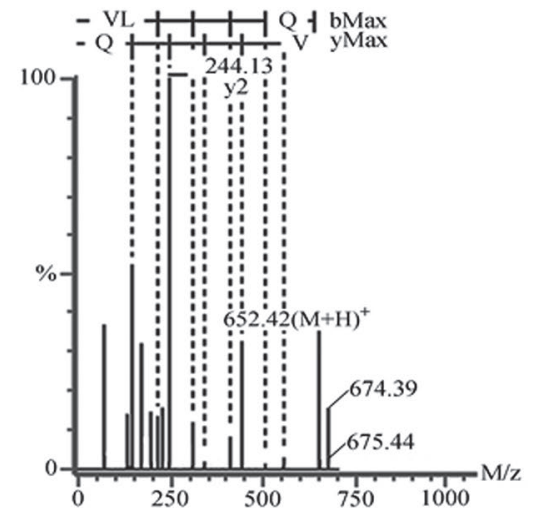

Figure 2. Analysis chart of the secondary mass spectrogram of sample A using Sephadex G-10 (Amersham Pharmacia Biotech, Uppsala, Sweden). (A) TDVEN = Thr-Asp-Val-Glu-Asn [ $\beta$-casein f(143-147)]. (B) LQPE = Leu-Gln-Pro-Glu $[\beta$-casein f(103-106)]. $(\mathrm{C})$ VLPVPQ $=$ Val-Leu-Pro-Val-Pro-Gln [ $\beta$-casein f(185-190)]. (D) VAPFPE = Val-Ala-Pro-Phe-Pro-Glu $\left[\alpha_{\mathrm{s} 1}\right.$-casein f(40-45)].

Figure 4 shows, the LQPE, VAPFPE, and VLPVPQ all significantly reduced NPC1L1 protein expression in Caco-2 cells, by $19.33 \pm 2.47 \%(P<0.05), 23.09$ $\pm 8.52 \%(P<0.05)$, and $52.1 \pm 3.77 \%(P<0.01)$, respectively, at $0.1,0.05$, and $0.1 \mathrm{mg} / \mathrm{mL}$, compared with the control.

\section{Effects of LQPE, VAPFPE, and VLPVPQ on mRNA Expression of ABCG8, ACAT2, MTP, ABCA1, SREBP1, and SREBP2 Transporters in the Caco-2 Cell Line}

According to the preliminary results, 3 peptides can be transported to the BL side of the Caco- 2 cell transwell model. Caco-2 cells were treated with $0.1 \mathrm{mg} /$ $\mathrm{mL}$ LQPE, $0.1 \mathrm{mg} / \mathrm{mL}$ VLPVPQ, $0.05 \mathrm{mg} / \mathrm{mL}$ VAPFPE, and cholesterol micelles on the AP side. Figure $5 \mathrm{~A}$ shows that treatment with each peptide induced a significant upregulation of $A B C G 8 \mathrm{mRNA}$ expression $(P<0.05)$. In particular, LQPE upregulated $A B C G 8$ mRNA expression by $398.1 \pm 23.27 \%(P<0.001)$ at $0.1 \mathrm{mg} / \mathrm{mL}$, VLPVPQ by $86.4 \pm 27.07 \%(P<0.05)$, and VAPFPE by $92.8 \pm 8.49 \%(P<0.05)$ compared with the control.
At $0.1 \mathrm{mg} / \mathrm{mL}$, VLPVPQ significantly decreased mRNA expression of ACAT2 by $43.37 \pm 5.47 \%(P<$ $0.05)$, whereas $0.1 \mathrm{mg} / \mathrm{mL}$ LQPE and $0.05 \mathrm{mg} / \mathrm{mL}$ VAPFPE had no significant effects on ACAT2 mRNA expression: $10.8 \pm 18.39 \%(P>0.05)$ and $14.4 \pm 6.5 \%$ $(P>0.05)$, respectively, compared with the control (Figure 5B).

The mRNA expression of $M T P$ was significantly inhibited by $0.1 \mathrm{mg} / \mathrm{mL}$ VLPVPQ $(25.87 \pm 9.29 \%, P$ $<0.05$ ), whereas $0.1 \mathrm{mg} / \mathrm{mL}$ LQPE and $0.05 \mathrm{mg} / \mathrm{mL}$ VAPFPE had no significant effect on mRNA of MTP: $11.28 \pm 1.52 \%(P>0.05)$ and $17.97 \pm 7.7 \%(P>0.05)$, respectively, compared with the control (Figure $5 \mathrm{C}$ ).

In the same experiments, the $A B C A 1, S R E B P 1$, and $S R E B P 2$ mRNA expression level variations were measured via RT-PCR analysis. As shown in Figure 5D, 0.1 $\mathrm{mg} / \mathrm{mL}$ VLPVPQ and LQPE significantly upregulated $A B C A l$ transcription by $203.9 \pm 8.44 \%$ and $220.8 \pm$ $36.42 \%(P<0.01)$, respectively, whereas $0.05 \mathrm{mg} / \mathrm{mL}$ VAPFPE had no significant effect on the transcription of ABCAl mRNA: $2.3 \pm 5.32 \%(P>0.05)$ compared with the control. No differences in the mRNA levels of SREBP1 or SREBP2 were detected among the 3 groups (Figure $5 \mathrm{E}-\mathrm{F}$ ). 

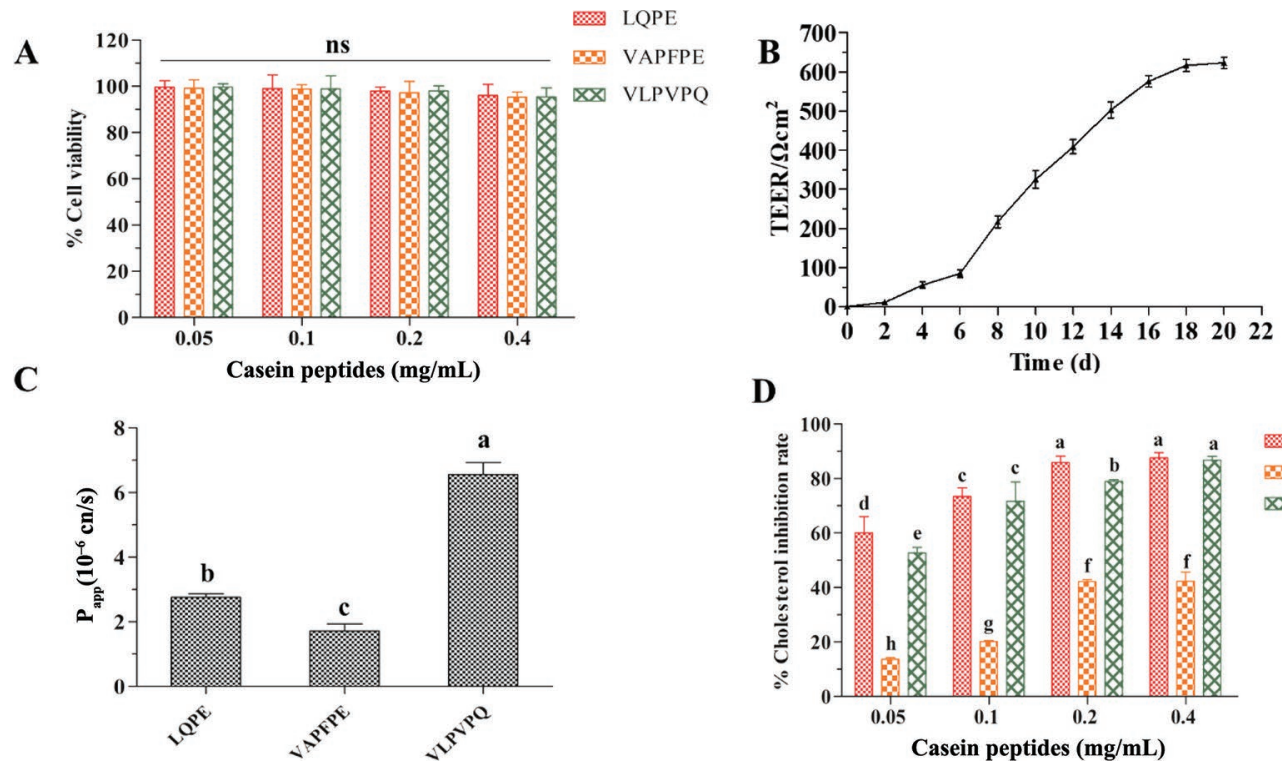

D

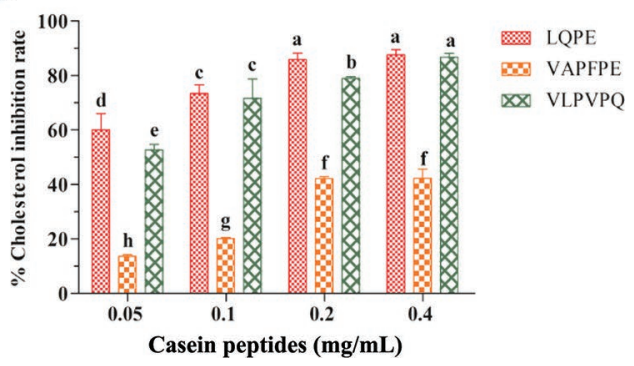

Figure 3. (A) Caco-2 cell viability after treatments with milk-derived peptides LQPE, VAPFPE, and VLPVPQ : results of 3-(4,5-dimethylthiazol-2-yl)-2,5-diphenyltetrazolium bromide (MTT) cell viability assay of Caco-2 cells after casein peptide treatments for $24 \mathrm{~h}$. Data are presented as average $\pm \mathrm{SD}$ with 5 samples per group. $P$-values $<0.05$ were considered significant (Tukey test on one-way ANOVA, SPSS Statistics 20; IBM Corp., Armonk, NY). (B) Transepithelial electrical resistance (TEER) value of Caco-2 cell monolayer. Data are presented as average $\pm \mathrm{SD}$, with 12 samples each time. (C) Permeability coefficient $\left(\mathrm{P}_{\text {app }}\right)$ values of LQPE, VAPFPE, and VLPVPQ. Data are presented as average $\pm \mathrm{SD}$ with 3 samples from each group. $P$-values $<0.05$ were considered significant (Tukey test on one-way ANOVA, SPSS Statistics 20 ). (D) Effects of different concentrations of peptides on water-soluble cholesterol uptake in Caco-2 cells. Data are presented as average \pm SD with 3 samples from each group. $P$-values $<0.05$ were considered significant (Tukey test on one-way ANOVA, SPSS Statistics 20).

\section{DISCUSSION}

The first objective of the present work is to prepare cholesterol-lowering peptides from casein protein. Milk casein was hydrolyzed with neutrase, purified using size-exclusion chromatography, and identified via UPLC-MS; TDVEN, LQPE, VLPVPQ, and VAPFPE were the first reported casein-derived peptides that have micellar cholesterol solubility inhibition activity.

The relationship between peptide properties and micellar cholesterol solubility inhibition activity is not yet clear. Table 2 shows the isoelectric point (pI) and GRAVY (grand average of hydropathicity) of identified casein-derived peptides with micellar cholesterol solubility inhibition activity. The peptides TDVEN and LQPE are hydrophilic, whereas VLPVPQ and VAPFPE are hydrophobic. Hydrophilic peptides may bind with micellar hydrophilic bile salts and then reduce micellar cholesterol solubility (Lapphanichayakool et al., 2017). Conversely, hydrophobic peptides may interact with cholesterol, hindering cholesterol solubilization into the micelles (Marques et al., 2015a,b; Lapphanichayakool et al., 2017). The pI of TDVEN, LQPE, VLPVPQ, and VAPFPE are 3.01, 3.28, 7.00, and 3.28, respectively. However, Lapphanichayakool et al. (2017) reported that $\mathrm{pI}$ of bile acid-binding activity peptides are in the range of 4 to 12. The effects of $\mathrm{pI}$ on micellar cholesterol solubility inhibition activity are not clear and need further research.

In addition, we performed a preliminary study on the water-soluble cholesterol absorption of LQPE, VLPVPQ, and VAPFPE in Caco-2 cell monolayer. The $\mathrm{P}_{\text {app }}$ value can predict in vivo absorption of substances: $\mathrm{P}_{\text {app }}$ values $<10^{-6} \mathrm{~cm} / \mathrm{s}$ indicate malabsorption $(0-20 \%) ; \mathrm{P}_{\text {app }}$ values between $10^{-6}$ and $10^{-5} \mathrm{~cm} / \mathrm{s}$ indicate moderate absorption of a substance (20-70\%); and $\mathrm{P}_{\text {app }}$ values $>10^{-5} \mathrm{~cm} / \mathrm{s}$ indicate that a substance is easy to absorb (70-100\%; Vieira et al., 2016). Peptides LQPE, VLPVPQ, and VAPFPE were bioaccessible and showed water-soluble cholesterol-lowering absorption activity, based on the inhibition of Caco- 2 cell cholesterol absorption experiments (Figure 3D). We hypothesize that, in addition to lowering cholesterol micelle concentration, another explanation for the ability of peptides to lower cholesterol may be the effects of the expression of proteins and enzymes that regulate cholesterol absorption in intestinal epithelial cells.

A polyhedral transmembrane protein that is abundant on the AP surface of the small intestinal infiltrate (Alrefai et al., 2007), NPC1L1 mediates the passage of cholesterol through the brush border membrane of the intestinal epithelium and is critical for cholesterol absorption (Altmann et al., 2004). The function of intestinal NPC1L1 is to transport free cholesterol from 
the intestinal lumen into enterocytes. Reduction of cholesterol absorption via intestinal NPC1L1 inhibition is one of the ways by which some functional foods and nutraceuticals decrease plasma cholesterol levels (Zhou et al., 2017). Three peptides in this study significantly reduced NPC1L1 protein levels compared with the control (Figure 4), which may be one of the mechanisms by which the 3 milk-derived peptides inhibit cholesterol absorption.

\section{$\mathbf{A}$ \\ Control LQPE VAPFPE VLPVPQ}

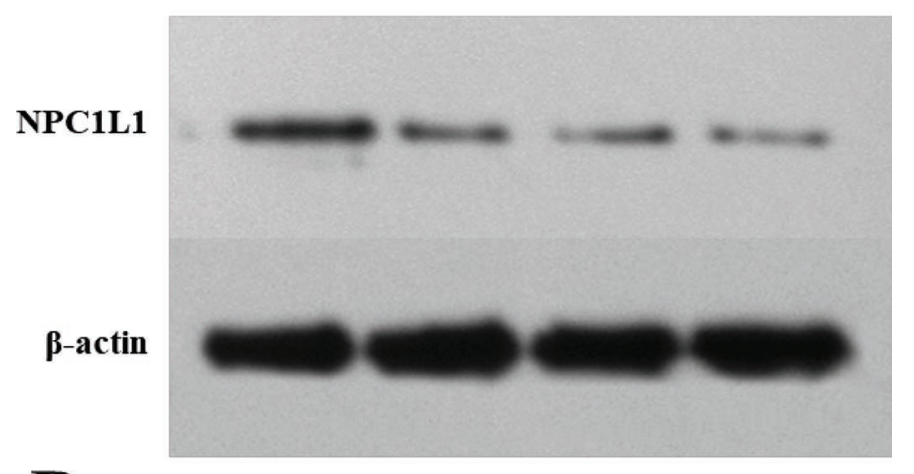

B

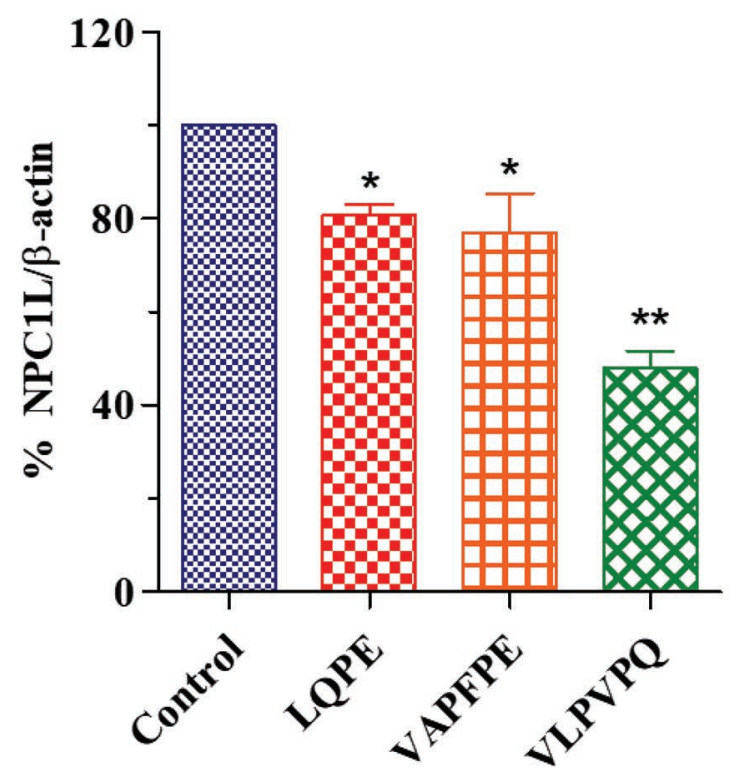

Figure 4. Effects of milk-derived peptides LQPE, VAPFPE, and VLPVPQ on Niemann-Pick C1-Like 1 (NPC1L) protein levels. Caco2 cells were treated with peptides for $24 \mathrm{~h}$. (A) NPC1L1 and $\beta$-actin immunoblotting signals were detected using specific anti-NPC1L1 and anti- $\beta$-actin primary antibodies. (B) mRNA level of NPC1L1 was quantified using ImageLab software (Bio-Rad, Hercules, CA) and normalized via $\beta$-actin signals. Data are presented as average \pm SD with 3 samples from each group. ${ }^{*} P<0.05,{ }^{* *} P<0.01$ versus control (Dunnett test on one-way ANOVA, SPSS Statistics 20; IBM Corp., Armonk, NY).
Next we speculated that the cholesterol-lowering activity of peptides may be regulated by other cholesterol absorption-related genes. Therefore, we performed RT-PCR experiments with other genes. A heterodimer formed in the endoplasmic reticulum, ABCG8 is negatively correlated with cholesterol absorption. The unabsorbed cholesterol in intestinal epithelial cells can return to the intestinal lumen via the action of ABCG8 (Yu et al., 2014) or by ACAT-regulated cholesterol esterification into cholesteryl esters from the plasma membrane into the endoplasmic reticulum (Tang et al., 2009). Figure 5A shows that the addition of these peptides can promote transcription of the cholesterol efflux gene $A B C G 8$ and the secretion of cholesterol from the cell to the outside, thereby inhibiting cell monolayer cholesterol absorption.

Additionally, ACAT2 plays a major role in facilitating cholesterol absorption. Following uptake of cholesterol into the enterocyte, the re-esterification of free cholesterol becomes a key step because cholesterol is secreted from the BL side in the form of esters (Wang et al., 2014). The ACAT2 gene is only expressed in small intestinal epithelial cells and hepatocytes. The main role of ACAT2 is to convert free cholesterol in the cell into cholesteryl ester (Castro-Torres et al., 2014), which has a positive effect on cholesterol absorption. Our results showed that VLPVPQ could downregulate ACAT2 transcription (Figure 5B), which suggests that VLPVPQ might be an ACAT2-specific inhibitor in enterocytes.

The microsomal triglyceride transfer protein (MTTP) consists of 4 MTTP $\alpha$ subunits and 4 MTTP $\beta$ subunits and is mainly involved in the secretion of apolipoprotein ApoB48 in the liver and small intestinal cells (Wang et al., 2015). This protein assembles the cholesteryl ester into chylomicrons, which are secreted through the BL membrane into the lymphatic system and then into the blood (Wang et al., 2015). Real-time PCR analysis demonstrated that LQPE and VAPFPE had no effect on MTP expression. However, VLPVPQ did downregulate $M T P$ mRNA (Figure 5C).

The protein ABCA1 is a cell membrane transport carrier that plays an important role in mediating reverse cholesterol transport and high-density lipoprotein production. The first step in reverse cholesterol transport is ABCA1-mediated cholesterol export from peripheral cells (Qian et al., 2017). It was shown that LQPE and VLPVPQ increase transcription of $A B C A 1$ and may promote the production of high-density lipoprotein, thereby reducing intracellular cholesterol levels (Figure 5D).

Sterol regulatory element binding protein is a conditional transcriptional activator involved in the 
regulation of cellular cholesterol metabolism in the endoplasmic reticulum (Horton et al., 1998). In human intestinal Caco-2 cells (Field et al., 2001), SREBP-2 is involved in an adaptive intestinal process of modulating the expression and activity of the intestinal apical sodium-dependent bile acid transporter in response to high cholesterol (Thomas et al., 2006). Alrefai et al. (2007) provided evidence for SREBP-2 involvement in the regulation of intestinal NPC1L1 expression. High cholesterol leads to suppression in the activity of intestinal SREBP-2 and a subsequent reduction in the expression of both NPC1L1 and apical sodium dependent bile acid transporter (ASBT), resulting in a concomitant decrease in cholesterol and bile acid absorption, favoring a decline in plasma cholesterol (Alrefai et al., 2007). High cholesterol inhibits the activity of intestinal SREBP-2, thereby reducing the expression of NPC1L1 and reducing intestinal cholesterol absorption (Alrefai et al., 2007). In this experiment, expression of SREBP2 in the 3 peptide-treated groups was not different from that of the control group (Figure 5E-F). This may be because cholesterol concentration is insufficient in the response of SREBP-2, and the specific mechanism needs to be further studied.

In conclusion, we found 3 new cholesterol-lowering peptides, LQPE, VLPVPQ, and VAPFPE, derived from milk casein hydrolysates in vitro. The cholesterollowering action was induced by inhibition of cholesterol absorption accompanying the suppression of micellar cholesterol solubility, and affects the expression of cholesterol absorption-related proteins and enzymes such as NPCL1 in intestinal epithelial cells. This study included only in vitro experiments on the cholesterollowering activity of 3 peptides obtained after casein hydrolysis. However, more studies are needed to fully understand the biological activity of the hypolipidemic peptides and the specific molecular mechanisms involved. Therefore, we are conducting animal experiments to study the cholesterol-lowering activity of casein hydrolysate peptides.
A

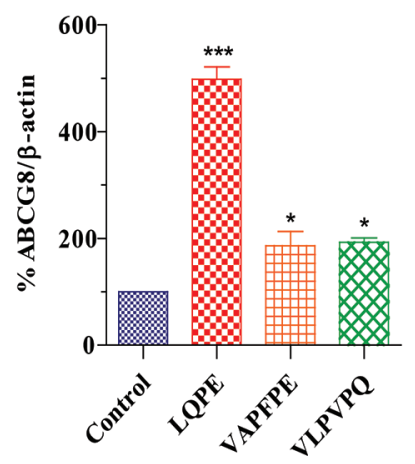

D

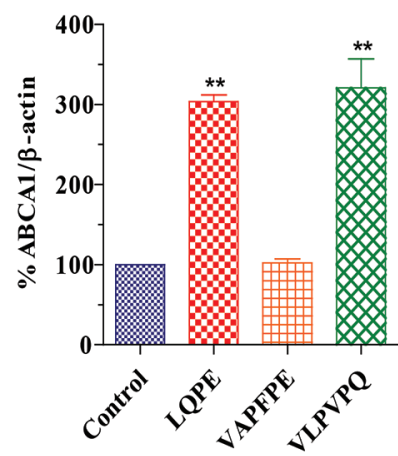

B

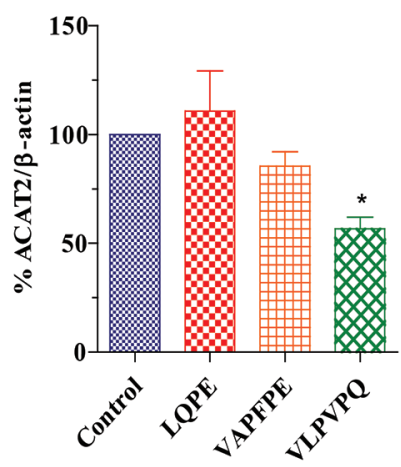

$\mathbf{E}$

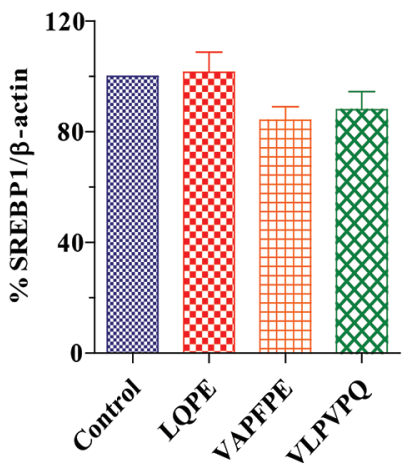

C

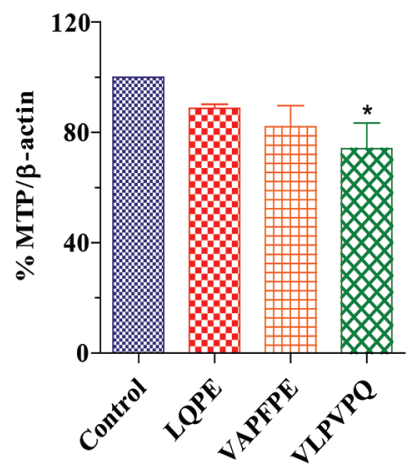

F

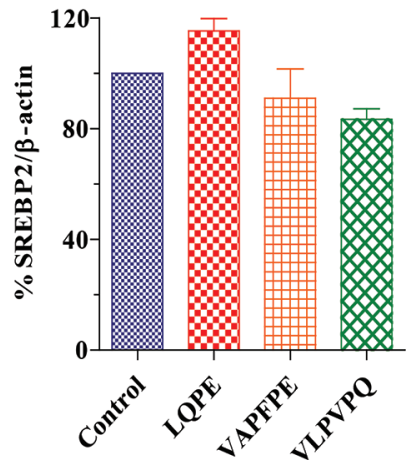

Figure 5. Effects of adding milk-derived peptides LQPE, VAPFPE, and VLPVPQ on the expression of ABCG8, ACAT2, MTP, ABCA1, SREBP1, and SREBP2. mRNA levels of ABCG8, ACAT2, MTP, ABCA1, SREBP1, and SREBP2 were quantified using ImageLab software (Bio-Rad, Hercules, CA) and normalized via $\beta$-actin signals. Data are presented as average \pm SD with 3 samples from each group. ${ }^{*} P<0.05$, ${ }^{* *} P<0.01$, and ${ }^{* * *} P<0.001$ versus control (Dunnett test on one-way ANOVA, SPSS Statistics 20; IBM Corp., Armonk, NY). 


\section{ACKNOWLEDGMENTS}

This work was supported by the National Natural Science Foundation of China (31972092, 31571852; Beijing), the "333 Project" Foundation of Jiangsu Province (BRA2017450; Nanjing, China), Ningbo University (China) State Key Laboratory for Quality and Safety of Agro-products (KF20190103), Jiangsu Agricultural Science and Technology Innovation Fund [CX (18) 3036; Nanjing, China], and the Jiangsu Science and Technology Department (BE 2018397; Nanjing, China). The authors have not stated any conflicts of interest.

\section{REFERENCES}

Alrefai, W. A.,, F. Annaba, Z. Sarwar, A. Dwivedi, S. Saksena, A. Singla, P. K. Dudeja, and R. K. Gill. 2007. Modulation of human Niemann-Pick C1-like 1 gene expression by sterol: Role of sterol regulatory element binding protein 2. Am. J. Physiol. Gastrointest. Liver Physiol. 292:G369-G376. https://doi.org/10.1152/ajpgi .00306 .2006 .

Altmann, S. W., H. R. Davis, L. J. Zhu, X. R. Yao, L. M. Hoos, G. Tetzloff, S. P. N. Iyer, M. Maguire, A. Golovko, M. Zeng, L. Q. Wang, N. Murgolo, and M. P. Graziano. 2004. Niemann-Pick C1 like 1 protein is critical for intestinal cholesterol absorption. Science 303:1201-1204. https://doi.org/10.1126/science.1093131.

Beermann, C., and J. Hartung. 2013. Physiological properties of milk ingredients released by fermentation. Food Funct. 4:185-199. https://doi.org/10.1039/C2FO30153A.

Boachie, R., S. Yao, and C. C. Udenigwe. 2018. Molecular mechanisms of cholesterol-lowering peptides derived from food proteins. Curr. Opin. Food Sci. 20:58-63. https://doi.org/10.1016/j.cofs.2018.03 .006 .

Braithwaite, M. C., C. Tyagi, L. K. Tomar, P. Kumar, Y. E. Choonara, and V. Pillay. 2014. Nutraceutical-based therapeutics and formulation strategies augmenting their efficiency to complement modern medicine: An overview. J. Funct. Foods 6:82-99. https:// doi.org/10.1016/j.jff.2013.09.022.

Castro-Torres, I. G., M. De la O-Arciniega, G. A. Bravo-Duarte, J. Gallegos-Estudillo, M. Á. Domínguez-Ortíz, and M. MartínezVázquez. 2014. Intestinal and hepatic Niemann-Pick C1L1 proteins: Future therapeutic targets for cholesterol gallstones disease? Eur. J. Pharmacol. 728:77-81. https://doi.org/10.1016/j.ejphar 2014.01.067.

Chen, Z.-Y., K. Y. Ma, Y. Liang, C. Peng, and Y. Zuo. 2011. Role and classification of cholesterol-lowering functional foods. J. Funct. Foods 3:61-69. https://doi.org/10.1016/j.jff.2011.02.003.

Duranti, M., M. R. Lovati, V. Dani, A. Barbiroli, A. Scarafoni, S. Castiglioni, C. Ponzone, and P. Morazzoni. 2004. The $\alpha$ ' subunit from soybean $7 \mathrm{~S}$ globulin lowers plasma lipids and upregulates liver $\beta$-VLDL receptors in rats fed a hypercholesterolemic diet. J. Nutr. 134:1334-1339. https://doi.org/10.1093/jn/134.6.1334.

El-Tantawy, W. H., and A. Temraz. 2019. Natural products for controlling hyperlipidemia. Arch. Physiol. Biochem. 125:128-135. https://doi.org/10.1080/13813455.2018.1441315.

Field, F. J., E. Born, S. Murthy, and S. N. Mathur. 2001. Regulation of sterol regulatory element-binding proteins by cholesterol flux in CaCo-2 cells. J. Lipid Res. 42:1687-1698.

Gaudet, D., J. P. Drouin-Chartier, and P. Couture. 2017. Lipid metabolism and emerging targets for lipid-lowering therapy. Can. J. Cardiol. 33:872-882. https://doi.org/10.1016/j.cjca.2016.12.019.

Guo, Y., J. Gan, Q. Zhu, X. Zeng, Y. Sun, Z. Wu, and D. Pan. 2018. Transepithelial transport of milk-derived angiotensin I-converting enzyme inhibitory peptide with the RLSFNP sequence. J. Sci. Food Agric. 98:976-983. https://doi.org/10.1002/jsfa.8545.

Horton, J. D., I. Shimomura, M. S. Brown, R. E. Hammer, J. L. Goldstein, and H. Shimano. 1998. Activation of cholesterol synthesis in preference to fatty acid synthesis in liver and adipose tissue of transgenic mice overproducing sterol regulatory element-binding protein-2. J. Clin. Invest. 101:2331-2339. https://doi.org/10.1172/ JCI2961.

Ito, M. K., S. Ganesan, G. I. Judd, A. Zargar, and A. J. Olyaie. 2012. Cyclosporine A reduces ATP-binding cassette transporter G5 (ABCG5) and G8 (ABCG8) gene expression and protein in Caco-2 cells. J. Clin. Lipidol. 6:292. https://doi.org/10.1016/j.jacl .2012.04.073.

Korhonen, H. 2009. Milk-derived bioactive peptides: From science to applications. J. Funct. Foods 1:177-187. https://doi.org/10.1016/ j.jff.2009.01.007.

Lammi, C., C. Zanoni, and A. Arnoldi. 2015. IAVPGEVA, IAVPTGVA, and LPYP, three peptides from soy glycinin, modulate cholesterol metabolism in HepG2 cells through the activation of the LDLR-SREBP2 pathway. J. Funct. Foods 14:469-478. https://doi .org/10.1016/j.jff.2015.02.021.

Lapphanichayakool, P., M. Sutheerawattananonda, and N. Limpeanchob. 2017. Hypocholesterolemic effect of sericin-derived oligopeptides in high-cholesterol fed rats. J. Nat. Med. 71:208-215. https:/ /doi.org/10.1007/s11418-016-1050-9.

Livak, K. J., and T. D. Schmittgen. 2001. Analysis of relative gene expression data using real-time quantitative PCR and the $2^{-\triangle \Delta C T}$ method. Methods 25:402-408. https://doi.org/10.1006/meth.2001 .1262 .

Marques, M. R., G. G. Fontanari, D. C. Pimenta, R. M. Soares-Freitas, and J. A. G. Arêas. 2015a. Proteolytic hydrolysis of cowpea proteins is able to release peptides with hypocholesterolemic activity. Food Res. Int. 77:43-48. https://doi.org/10.1016/j.foodres .2015.04.020.

Marques, M. R., R. A. Soares Freitas, A. C. Correa Carlos, E. S. Siguemoto, G. G. Fontanari, and J. A. Areas. 2015b. Peptides from cowpea present antioxidant activity, inhibit cholesterol synthesis and its solubilisation into micelles. Food Chem. 168:288-293. https:// doi.org/10.1016/j.foodchem.2014.07.049.

Martínez-Augustin, O., B. Rivero-Gutierrez, C. Mascaraque, and F. Sanchez de Medina. 2014. Food derived bioactive peptides and intestinal barrier function. Int. J. Mol. Sci. 15:22857-22873. https: //doi.org/10.3390/ijms151222857.

Mathur, S. N., E. Born, S. Murthy, and F. J. Field. 1997. Microsomal triglyceride transfer protein in $\mathrm{CaCo}-2$ cells: Characterization and regulation. J. Lipid Res. 38:61-67.

Moriyama, T., K. Kishimoto, K. Nagai, R. Urade, T. Ogawa, S. Utsumi, N. Maruyama, and M. Maebuchi. 2004. Soybean $\beta$-conglycinin diet suppresses serum triglyceride levels in normal and genetically obese mice by induction of $\beta$-oxidation, downregulation of fatty acid synthase, and inhibition of triglyceride absorption. Biosci. Biotechnol. Biochem. 68:352-359. https://doi.org/10.1271/bbb.68.352.

Musso, G., R. Gambino, and M. Cassader. 2010. Emerging molecular targets for the treatment of nonalcoholic fatty liver disease. Annu. Rev. Med. 61:375-392. https://doi.org/10.1146/annurev.med.60 .101107 .134820 .

Nagaoka, S. 2018. Mystery of cholesterol-lowering peptides, lactostatin and soystatin. J. Agric. Food Chem. 66:3993-3994. https://doi .org/10.1021/acs.jafc.8b01025.

Nagaoka, S. 2019. Structure-function properties of hypolipidemic peptides. J. Food Biochem. 43:e12539. https://doi.org/10.1111/jfbc .12539 .

Nagaoka, S., T. Awano, N. Nagata, M. Masaoka, G. Hori, and K. Hashimoto. 1997. Serum cholesterol reduction and cholesterol absorption inhibition in CaCo-2 cells by a soyprotein peptic hydrolyzate. Biosci. Biotechnol. Biochem. 61:354-356. https://doi.org/ 10.1271/bbb.61.354.

Nagaoka, S., Y. Futamura, K. Miwa, T. Awano, K. Yamauchi, Y. Kanamaru, K. Tadashi, and T. Kuwata. 2001. Identification of novel hypocholesterolemic peptides derived from bovine milk $\beta$-lactoglobulin. Biochem. Biophys. Res. Commun. 281:11-17. https://doi.org/10.1006/bbrc.2001.4298.

Nagaoka, S., A. Nakamura, H. Shibata, and Y. Kanamaru. 2010. Soystatin (VAWWMY), a novel bile acid-binding peptide, decreased micellar solubility and inhibited cholesterol absorption in rats. 
Biosci. Biotechnol. Biochem. 74:1738-1741. https://doi.org/10 $.1271 /$ bbb. 100338 .

Picariello, G., G. Iacomino, G. Mamone, P. Ferranti, O. Fierro, C. Gianfrani, A. Di Luccia, and F. Addeo. 2013. Transport across Caco-2 monolayers of peptides arising from in vitro digestion of bovine milk proteins. Food Chem. 139:203-212. https://doi.org/10 .1016/j.foodchem.2013.01.063.

Qian, H., X. Zhao, P. Cao, J. Lei, N. Yan, and X. Gong. 2017. Structure of the human lipid exporter ABCA1. Cell 169:1228-1239. https://doi.org/10.1016/j.cell.2017.05.020.

Sienkiewicz-Szłapka, E., B. Jarmolowska, S. Krawczuk, E. Kostyra, H. Kostyra, and K. Bielikowicz. 2009. Transport of bovine milkderived opioid peptides across a Caco-2 monolayer. Int. Dairy J. 19:252-257. https://doi.org/10.1016/j.idairyj.2008.10.007.

Song, B. L., C. H. Wang, X. M. Yao, L. Yang, W. J. Zhang, Z. Z. Wang, X. N. Zhao, J. B. Yang, W. Qi, X. Y. Yang, K. Inoue, Z. X. Lin, H. Z. Zhang, T. Kodama, C. C. Chang, Y. K. Liu, T. Y. Chang, and B. L. Li. 2006. Human acyl-CoA:cholesterol acyltransferase 2 gene expression in intestinal Caco-2 cells and in hepatocellular carcinoma. Biochem. J. 394:617-626. https://doi.org/10 $.1042 / B J 20051417$.

Srinivasan, B., A. R. Kolli, M. B. Esch, H. E. Abaci, M. L. Shuler, and J. J. Hickman. 2015. TEER measurement techniques for in vitro barrier model systems. J. Lab. Autom. 20:107-126. https://doi .org/10.1177/2211068214561025.

Suwal, S., R. Silveira Porto Oliveira, M. Pimont-Farge, A. Marciniak, G. Brisson, Y. Pouliot, and A. Doyen. 2019. Formation of stable supramolecular structure with $\beta$-lactoglobulin-derived self-assembling peptide f1-8 and bovine micellar caseins. J. Agric. Food Chem. 67:1269-1276. https://doi.org/10.1021/acs.jafc.8b05584.

Tang, W., Y. Ma, L. Jia, Y. A. Ioannou, J. P. Davies, and L. Yu. 2009. Genetic inactivation of NPC1L1 protects against sitosterolemia in mice lacking ABCG5/ABCG8. J. Lipid Res. 50:293-300. https:// doi.org/10.1194/jlr.M800439-JLR200.

Thomas, C., J. F. Landrier, D. Gaillard, J. Grober, M. C. Monnot, A. Athias, and P. Besnard. 2006. Cholesterol dependent downregulation of mouse and human apical sodium dependent bile acid transporter (ASBT) gene expression: molecular mechanism and physiological consequences. Gut 55:1321-1331. https://doi.org/10 $.1136 /$ gut.2005.085555.

Vieira, E. F., J. das Neves, R. Vitorino, D. Dias da Silva, H. Carmo, and I. M. P. L. V. O. Ferreira. 2016. Impact of in vitro gastrointestinal digestion and transepithelial transport on antioxidant and ACE-inhibitory activities of brewer's spent yeast autolysate. J. Agric. Food Chem. 64:7335-7341. https://doi.org/10.1021/acs .jafc.6b02719.

Wang, X., L. Guan, Y. Zhao, L. Lei, Y. Liu, K. Y. Ma, L. Wang, S. W. Man, J. Wang, Y. Huang, and Z. Y. Chen. 2015. Plasma cholesterol-lowering activity of dietary dihydrocholesterol in hypercholesterolemia hamsters. Atherosclerosis 242:77-86. https:// doi.org/10.1016/j.atherosclerosis.2015.06.046.
Wang, Y., X. Yi, K. Ghanam, S. Zhang, T. Zhao, and X. Zhu. 2014 Berberine decreases cholesterol levels in rats through multiple mechanisms, including inhibition of cholesterol absorption. Metabolism 63:1167-1177. https://doi.org/10.1016/j.metabol.2014.05 .013 .

Xiao, C., S. Dash, C. Morgantini, R. A. Hegele, and G. F. Lewis. 2016. Pharmacological targeting of the atherogenic dyslipidemia complex: The next frontier in CVD prevention beyond lowering LDL cholesterol. Diabetes 65:1767-1778. https://doi.org/10.2337/ db16-0046.

Yamauchi, R., K. Ohinata, and M. Yoshikawa. 2003. $\beta$-Lactotensin and neurotensin rapidly reduce serum cholesterol via $\mathrm{NT}_{2}$ receptor. Peptides 24:1955-1961. https://doi.org/10.1016/j.peptides 2003.10.003.

Yang, F., G. Chen, M. Ma, N. Qiu, L. Zhu, and J. Li. 2018. Fatty acids modulate the expression levels of key proteins for cholesterol absorption in Caco-2 monolayer. Lipids Health Dis. 17:32. https:/ /doi.org/10.1186/s12944-018-0675-y.

Yu, X. H., K. Qian, N. Jiang, X. L. Zheng, F. S. Cayabyab, and C. K. Tang. 2014. ABCG5/ABCG8 in cholesterol excretion and atherosclerosis. Clin. Chim. Acta 428:82-88. https://doi.org/10.1016/j .cca.2013.11.010.

Zhang, H., G. E. Bartley, H. Zhang, W. Jing, C. K. Fagerquist, F. Zhong, and W. Yokoyama. 2013. Peptides identified in soybean protein increase plasma cholesterol in mice on hypercholesterolemic diets. J. Agric. Food Chem. 61:8389-8395. https://doi.org/ $10.1021 / \mathrm{jf4022288}$

Zhang, H., W. H. Yokoyama, and H. Zhang. 2012. Concentrationdependent displacement of cholesterol in micelles by hydrophobic rice bran protein hydrolysates. J. Sci. Food Agric. 92:1395-1401. https://doi.org/10.1002/jsfa.4713.

Zhao, L. Y., W. Huang, Q. X. Yuan, J. Cheng, Z. C. Huang, L. J. Ouyang, and F. H. Zeng. 2012. Hypolipidaemic effects and mechanisms of the main component of Opuntia dillenii Haw. polysaccharides in high-fat emulsion-induced hyperlipidaemic rats. Food Chem. 134:964-971. https://doi.org/10.1016/j.foodchem.2012.03.001.

Zhou, X., F. Ren, H. Wei, L. Liu, T. Shen, S. Xu, J. Wei, J. Ren, and H. Ni. 2017. Combination of berberine and evodiamine inhibits intestinal cholesterol absorption in high fat diet induced hyperlipidemic rats. Lipids Health Dis. 16:239. https://doi.org/10.1186/ s12944-017-0628-x.

\section{ORCIDS}

Daodong Pan @ \ttps://orcid.org/0000-0002-5299-644X

Zhen Wu (ํ) https://orcid.org/0000-0002-3607-6440

Yangying Sun (1) https://orcid.org/0000-0001-7284-3558

Yuxing Guo @ https://orcid.org/0000-0003-2935-9781 